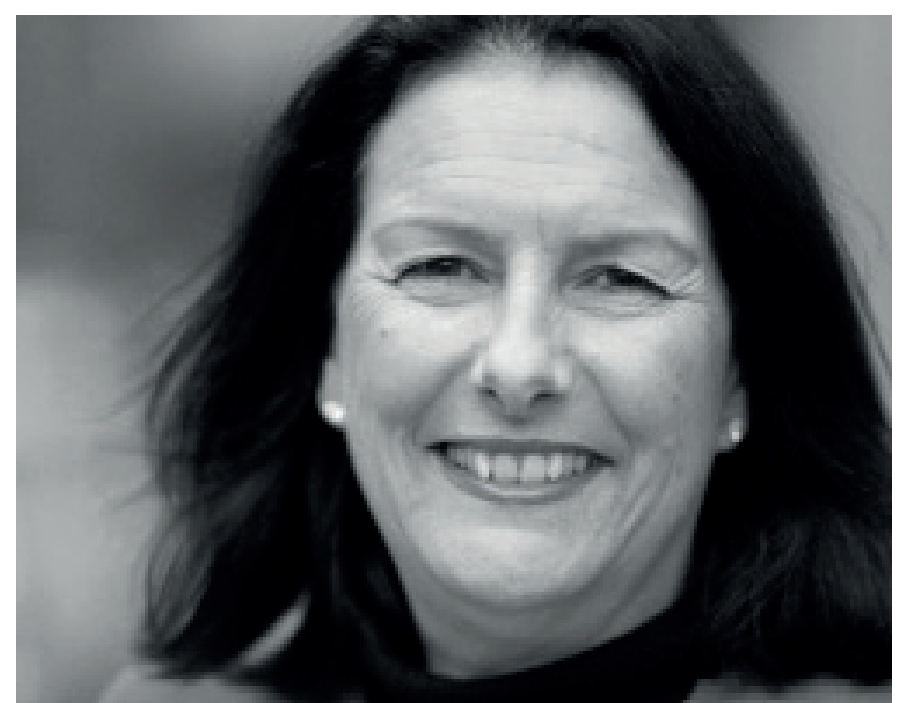

\section{RACHEL COOPER}

PhD; Professor of Design Management at the University of Lancaster; Chair of the Lancaster Institute for the Contemporary Arts; co-Director of ImaginationLancaster; co-Director of HighWire r.cooper@lancaster.ac.uk

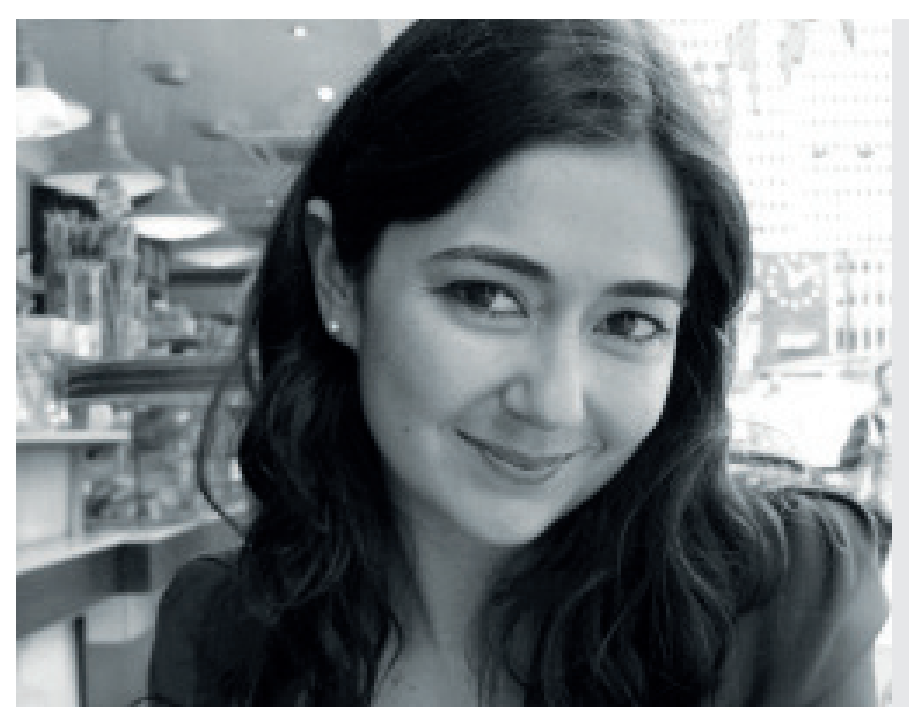

\section{SARA GANCHO}

Ms; PhD Design Student in Lancaster Institute for the Contemporary Arts

s.gancho1@lancaster.ac.uk

\title{
BRANDING TODAY - THE IMPORTANCE OF DESIGN IN SOCIAL MEDIA STRATEGY
}

\section{BRANDING HOJE: A IMPORTÂNCIA DO DESIGN NA ESTRATÉGIA DE MÍDIA SOCIAL}

\author{
RESUMO
}

Este artigo é uma breve discussão sobre o papel do design na gestão das marcas para mídia social. $\mathrm{O}$ artigo trata de alguns dos problemas de marca hoje e como a comunicação está mudando a relação entre empresas 
e consumidores. No contexto de branding para a mídia social o artigo compreende como a estratégia de design pode ajudar marcas a se envolver melhor com seus clientes e aperfeiçoar a sua experiência integral. Marcas devem ser visionária e enfrentar os diferentes esferas de potencial que os espera com design. São dados dois exemplos e suas abordagens de como o design pode ajudar na estratégia integral de mídia social das marcas.

\section{PALAVRAS CHAVE}

Branding. Design. Estratégia.

\section{ABSTRACT}

This article is a brief discussion into the role of design when branding for social media. It talks about some of the problems of branding today and how communication is changing the relationship between companies and consumers. In the context of branding for social media it understands how design strategy can help brands better engage with their clients and improve their overall experience. Brands must be visionary and embrace the different realms of potential that awaits them with Design. Two examples are given and their approach on how Design can help in the overall brand's social media strategy.

\section{KEYWORDS}

Branding. Design. Strategy.

\section{INTRODUCTION}

Consumers are used to regarding a brand as an important aspect of a product, and it can also add value to a product or service. The brand also carries the reputation of a product or company. People often have and image or an idea of a brand and they associate it with a product, service, trademark, or other image-related asset, e.g., the Shell sign. A brand can be regarded as a trusted, reliable product or service whose use brings predictable results and experiences. Others can view the brand as an economic asset and tangible expression of what accountants call "good will", that attempts to put a dollar value on an otherwise 
intangible corporate possession (Moon, Michael and Millison 2000).

Successful brands have their name recognized by the audience and that builds strategic awareness. Branding is more important today than ever due to the huge amount of advertising, media fragmentation, the commoditization of products, and the seemingly limitless choices consumersare offered in just about every product category (O'Malley 2010).

Brands can be perceivedas influential regarding the buyers decisions. They can create an emotional bond of trust that isnot always based on logic or intellectual reasoning. The brand also helps to increase acompany or product/service value,enhancing it by association (Kapferer 1997).

Branding is now the most important aspect of business, and everyone wants to measure its value. If you have a powerful brand your business will bloom. It becomes increasingly more important to make the consumers see that your brand is the only one that could fill all their needs and desires (Millward Brown 2009).

Branding has become part of pop culture. Numerous products have a brand identity: from common table salt to designer clothes. Noncommercially, branding can also apply to the marketing of entities, which supply ideas or promises rather than goods and services - such as political parties or religious organizations. (Ellwood 2002).

Brands have evolved into a powerful marketing asset. Starting from being just a message about the products identity, they are now something with its own concept, with its own identity. A brand represents the value of a company or organization. Through out its strong identity a brand can create relationships with its consumers, with the people who work directly with it (employees, suppliers, etc.). These relationships can be possible if the brand fulfills the stakeholder's aspirations. The better this relationships are, the better the probability of obtaining a long term relationship that will lead to preference, loyalty and an interest to invest. This paper will focus on the role of design for developing branding strategy in the digital age.

\section{BRANDING IN SOCIAL MEDIA TODAY}

In the article "The lure of global branding" (Aaker \& Joachimsthaler 1999) It is said that most companies are viewing the world as their potential 
global market, and that brand builders want to globalize their own brands in a worldwide dimension, following what appears to be a market trend. They are attracted by high profile cases of success but have no idea about how risky it all could be. According to David Aaker and Erich Joachimsthaler, in order to create a global brand we have to have global leadership. Global leadership is not obtained instantaneously; companies must use structures, processes and cultures to allocate brand-building resources in a global way. Aaker and Joachimsthaler describe four methods to achieve global brand leadership. Firstly, they believe that companies have to stimulate the sharing of insights and feedback for best practices across countries and try and embrace change instead of just saying: "it won't work here". Secondly, companies should rely on a common brand-planning process, consistency across markets and products. Thirdly,companiesshould assign global managerial responsibility for brands in order to fight local bias. Fourthly,companiesneed to develop and execute brilliant brand building strategies before stepping into the global market, otherwise branding will just happen on its own, and it could as easily fail or succeed, without control over it (Aaker \& Joachimsthaler 1999).

Every year, Interbrandevaluates brands that make a great deal of investment in their businesses. Neumeier (2003) says that even though companiesinvest time, energy, resources and study in their brands, most of them still care more about sales, services, quality and marketing and branding just happens while undertaking other endeavors.

Companies are trying to isolate branding from other assets in order to study, measure, manage and influence the process, rather than just let it happen. However, brand managers, strategists and researchers are discovering that it takes more than strategy to build a brand: it takes strategy and creativity (design) together (Neumeier 2003).

In most companies, the Marketing Department is separated from the Design Department.(Neumeier 2009). Designers learn about what the Marketing Department is doing through briefings for some advertising campaign, sub-brand creation, sales launch, event promotion, and so on. Neumeier defendsthat on one side we have the strategists and marketing people who favor left-side brain thinking, and on the other side we have the designers and creative who favor right-side brain thinking. What happens is that the left-side brainreasoningdoes not always know what the right-side brain thinking process is doing and vice-versa. When this happens, strategy 
and creativity separated from one another, which leads to a brand gap: "It can cause a brilliant strategy to fail where it counts most, at the point of contact with the costumer, or it can doom a bold creative initiative before it is even launched, way back at the planning stage" (Neumeier 2009).

The author also states that if the gulf exists it can separate a company from its costumers so completely that the company ceases to communicateany message at all.A brand gap can have two possible outcomes:

1) it creates a natural barrier to communication and

2) it creates a natural barrier to competition.

A strong and clear brand communication goes straight into people's minds without any message distortion. Brands that can reach out to people and overcome this gap can start to build a relationship with their costumers and initiate the foundations of charismatic brands. The charismatic brands often appear in everyday culture, are of highly mentioned and can be characterized by the people's belief that there are no substitutes for them. Therefore, charismatic brands usually dominate their market's shares from around $50 \%$ or higher, and get the highest price premiums (Neumeier 2003).

Brands have enjoyed a meteoric rise according to Kornberger (2011) and are the mechanism that tries to connect organizations closer to people. Nowadays brands seduce us into consumerism but at the same time they are also cultural forms that allow us to express ourselves.

For example,with NIKEiD [1] shoes customization, where the brand leverages advertising as social engineering while turning it into an art form at the same time (see figure 1).

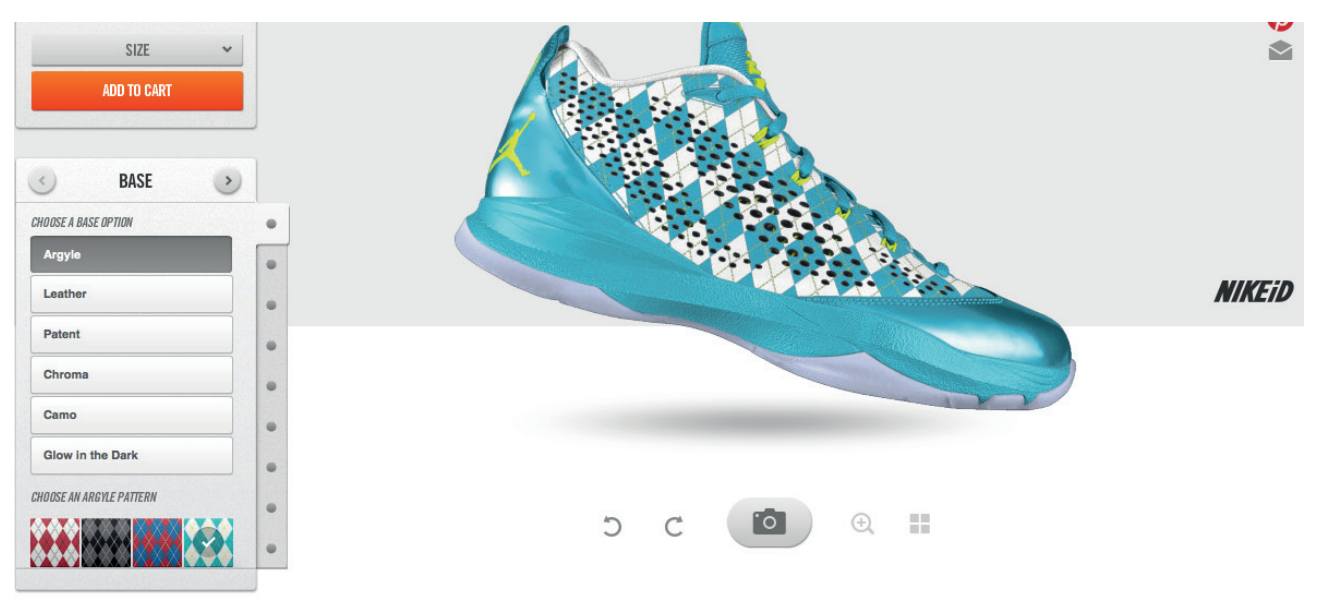

Figure 1: NikeiD 
Brands enable the individual to construct one's identity on the basis of one's consumption patterns. Brands have become the resource for identity formation. They are like ready-made elements(Warhol, Duchamp) for styling our lives. $\mathrm{H}$. Douglas says that consumers want to be the protagonist of their own lives, but they want the story written out for them. Brands in that perspective could provide the narratives they live by, because they represent values, not functionality. They are able to turn products into social meanings and consumption into a social phenomenon. Above all, in this information overuse driven world brands provide a safe haven because they provide us with some certainties, clarity and stability(Kornberger, 2011).

However, the problem has changed, and according to Kornberger (2011) the challenge now is not so much controlling the internal production process but to interact with one's environment and engage with it in a cocreative and innovative activity.

"The brand is the only interface for co-creation. Especially in the nonmediated media of the internet, brands are the only anchor point that provides stability and recognition". Consumers are relating to brands more directly as organizations lose control over production and distribution. "Brands are emerging as a new interface between consumption and production".

In a globalized world this impacts brands as well. We are shifting from the service based economy of the late $20^{\text {th }}$ century into the "experience economy" or, as the Nomura Economic Research Institute describes it, "The age of creativity".

Brands need to match the shifts expressed by the economic model and develop experiential customer interfaces. These will fall into the $5 \mathrm{I}$ 's brand dimensions, i.e., identify, inform, imagine, immerse and intrigue. Businesses need to define a balanced strategy for the bricks-to-clicks [2] paradigm, as well as the new economy of clicks-to-bricks [3]. They need to create synergy across the traditional and the new media rather than remain with a single one (Ellwood 2002).

According to Meyers and Gerstman, most of the cyberspace entrepreneurs believe that the Internet is just another way/tool to communicate their message, and that they do not need to resort to different strategies (other then the ones they have already) in order to promote and sell their products and services(Meyers, Herbert M. and Gerstman 2001).

According to Zyman (1999:p.1),"Traditional Marketing is not dying 
- it is dead", and the ability to move the masses has been lost partly because of technology. Technology has created a consumer's democracy because it gives people a wide range of choices, and in order to have the consumer's attention, companies need to find ways to relate/speak to small groups of people and individuals instead of trying to appeal to the masses/wider audiences. Therefore, it is important to know the individual and their individual groups. An interesting way to approach this could be analysingsocial networks (Zyman 1999).

Ollins (2003) defendsthat brands are ideally suited for the age of the global village. The branding mechanism was designed for and by modern techniques to sell products by creating and projecting simple and clear ideas, over and over again. Today, Branding has become more successful than what its creators expected.

Meyers and Gerstmandefendthat the Internet may have offered the perfect solution for marketers to solve their problems with communication with clients. It createdopportunities to interface withindividuals and smalltargeted groups at any given moment. Even if a product is not marketed directly on the Internet, marketers use its channelsto communicate a positive brand personality and increase its value towards consumers (Meyers, Herbert M. and Gerstman 2001).

Brand presence on the Internet has to have continuity and interface/ interact with other communication media in order to survive.

According to Meyers and Gerstman, some brands are classifiable as "Instant". Such brands surface the Internet daily and have a short life spam. While the benefits that the technology offers are captivating, in order for a brand to succeed it has to be developed and maintained with thoughtfulness foresight and always in context with the target audience. So technology, if used frivolously, can work against the company itself(Meyers, Herbert M. and Gerstman 2001)

Upshaw (1995:p.10) states that "The splintering of conventional media and the advent of interactive communications has presented marketers with a two-edged blade: New media offers more opportunities to seed brand messages via narrow targeting, but they will also make it more difficult for many brands to efficiently reach large enough audiences to create profitable volume levels"(Upshaw 1995).

Although Marketers control the placement of their brands and 
packages on store shelves, they canot control it on the cyberspace, and this has become a major concern.

A brand is now the image of what consumers have of it; it is no longer what advertising agencies say it is. Modern-day branding has to adapt to an environment where consumers can talk to each other and their conversations are spread far and wide and are even archived and available to inform future users There are consumers blogging about their preferences and how a company treated them, every day. Consumers can review and rate products and give each other feedback and recommendations. A brand shouting its message is no longer the only source of information; consumers have many other sources of trust and objective opinions (Zyman 1999).

A brand can say it is famous for agreat customer service, but the ultimate factor is going to be how consumers actually perceive the brand. How current consumers describe the brand to others has far greater weight in the minds of future consumers. Furthermore, digital channels break through information and geographic boundaries. Consumers can now compare features and prices of dozens of similar products, e.g., digital cameras.Consumers no longer rely on afew in-store selections and the limited information they provide. Consumers can also buy products that better suit their needs, even if those products arenot available in local stores, turning to online businesses. Branding claims are irrelevant. Consumers are empowered now and will speak up (Conley, 2008).

We can say that a brand's reputation is earned over time and the brand is a symbol of this reputation, which helps new customers simplify their purchase decision. Fake brands, on the other hand, are the ones that fabricate what they think customers should think or feel about them; typically, they shout the loudest at consumers, writes (Conley 2009).

Branding as come to a point where it is hardly impossible to convey to all of the consumer's habits and expectations. So we need to innovate. "True innovation", as Conley (2009) refers to it, is hard work. However, we now have the tools and venues where feedback from customers is readily and continuously available. Advertisers can review user feedback, comments, and archived suggestions. Instead of branding, companies practice brand stewardship. Brand stewardship is defined as constantly being aware of what your customers think of your product and what they need. With this knowledge, advertisers are empowered to innovate products and services, 
to substantiate their promise to customers and earn a reputation over time, i.e., the brand.

Conley introduces a new concept called brand gravity, which is the accumulated reputation that attracts new customers to buy and keeps current customers in orbit. The new branding process is true and rapid. It calls for continuous innovation, informed by real-time consumer feedback that leads to consistent delivery of stellar products and an earned brand reputation. That is why branding (as it is mostly done today, i.e., shouting made-up messages) is ineffective, irrelevant, irritating, now that there is a correct way to achievebranding excellence (Conley, 2008).

Storytelling is a concept that has arrived in branding literature, and has connections with Design. It is a touch point between subject areas that could benefit branding. It could be one of the answers to branding excellence. Storytelling and stories itself have been connected with user experience design as scenarios, storyboards, flow chats, personas and other techniques that are used to communicate how a new design will operate. As part of a user experience design, storytelling serves to ground the work in a real context. It enables design to connect with ideas for the people who will eventually use the product or service(Quesenbery, Whitney and Brooks 2010).

Design stories can be useful tools in several phases of the design process, including the design phase, the design communication or documentation phase and in formative evaluation (Parrish 2006). Many organizations try to manage corporate images through a mix of corporate advertising, corporate storytelling, customer relationships management and other marketing models referred above as well as marketing communication and public relations techniques(Hatch \& Schultz 2003).

\section{DESIGN STRATEGY IN SOCIAL MEDIA}

Design strategy tunes team intelligence, creativity and makes a significant impact in customer's life, both functional and emotional. The design process is easy to follow but should be taken into the corporate plans and strategies in order to be at its full potential. The design approach is about combining the three gears of design with a design mindset, allowing the organization to discover ways of capitalize, explore new activities and set 
strategies to evolve thebusiness model (Fraser 2007).

Using Design strategy to develop tools for Social media is something that is being done with high levels of success. We illustrate this by presenting the case of Diesel [4] (see figure 2), whichoriginated from a simple premise, in 2010. Diesel supplied their point of purchase stands and kiosks with a photographic camera, through which people that came to the store would take a picture of the product they were trying out,e.g., a sweater, or jeans. The customer would then be able to post the photo on their Facebook wall, showcasing the item. The photo would then be published on their Facebook profile wall and on the screen, where friend could comment, saying if they liked it or not. Diesel expectedthat the user's friends saw that this person was at the store to buy a product, and from then on they had a high grow on fans.What the company did not predict asthe outcome of this campaign was the creation of a different social media concept on store. The campaignhad a massive outcome in PR as it turned out to be a very effectiveadvertising tool. $40 \%$ of the fans heard about the campaign from other places then the store, and other websites that had nothing to do with the communication strategy. Nowadays we cannot look at a social media strategy or digital strategy in an isolated way. This 'design storytelling experience' gives the consumer a sense of belonging and allows him to engage with the brand in a one-toone perspective.We have to see how we can conjugate not only with our business but with our global communication strategy.

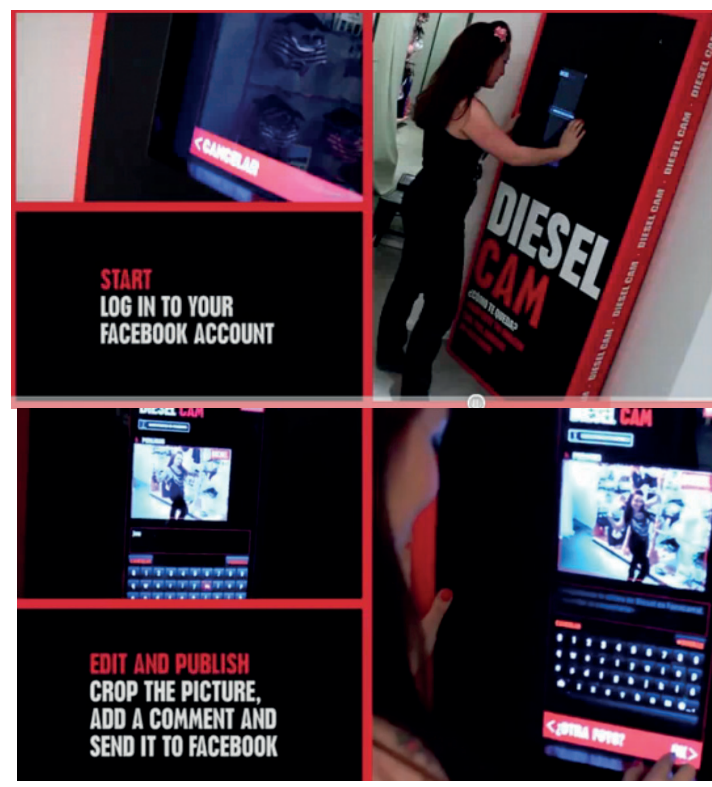

Figure 2: Diesel Social Media Campaign 
It is generally accepted that it is important to have an online presence on the web, but how can business be sure that their brands are being relevant in all platforms? How can it maintain a position of relevance and consistency in all the different types of channels? The answer to this is Design strategy.

Because of the Internet, brand strategies have gone through significant transformations. In order to succeed in a computer mediated environment brands need to use design to build relationships, enable interactivity and better tailor offerings for the online world (Christodoulides 2009).

The social media presence needs to be developed strategically to coordinate the different views of the organization, its aims and activities, in order to plan the different opportunities that arise in social media and social networking. (McDonald 2007).

\section{CONCLUSIONS}

Combining Design in social media allows the design leader to better understand the consumer. Media channels might have been the marketing department's territory, but today it fits into the design leader skills as well. As the role of design in business gains importance, the role of the design manager in adapting design to this new media as well.

Design is the materialization of all thinking and was already important before social media came along, in traditional mediums such as advertising. Ultimately it is through image that we capture an audience, and channels like Facebook are very visual. Design about creating that first impactbut also about developing the strategy that makes storytelling happen for the user. We need to fit the right images with the particulars of the different platforms. Design can create different synergies between platforms and allied with its branding knowledge can be a powerful asset.

Advertisement can no longer be understood as a monologue; there has to be a dialogue with the consumer.For that to happen, communication has to go online and it has to make sense in that medium. Designers have the tools, expertise and skills to make social media branding success a reality, whether it's through storytelling or other social media strategies. They can improve consumer's engagement with the brand; they can attract more customers and therefore generate more income. They also can make the brand more aware in people's minds and in their everyday lives, thus 
improving brand equity in general. Designers are also experts at innovation and in delivering new technological or/and methodological approaches whether it is a new service design or a new product design. We believe that designers should be engaging in social media branding endeavorsbecause they havemanagement, strategy and creativity skills that, combined together with market knowledge and consumer reach, make up for the perfect social media entrepreneur.

To summarise then, design can create differentiation through branding and that can have a serious impact on consumer behaviour, which can help companies sell their services and/or products more efficiently. Design strategy incorporates cognition, emotion, message and also the social relationship with the consumer. Consumers have aesthetic preferences that may come from design principles and can be quite diverse according to their experience with design itself. Design in conjunction with brand identity development builds brand equity and brand architecture, all powerful assets in Social Media.

\section{NOTES}

[1] http://www.nike.com/us/en_us/c/nikeid, accessed on 18/01/2014

[2] Is a business model by which a company integrates both offline (bricks) and online (clicks) presences.

[3] Is an e-commerce business model from the click ( online) to the bricks (store).

[4] http://allfacebook.com/diesel-cam-brings-facebook-to-the-fitting-room_ b14236 accessed on 17/01/2014

\section{REFERENCES}

AAKER, D.A.; JOACHIMSTHALER, E. The lure of global branding. 1999, pp.1-7.

CHRISTODOULIDES, G. Branding in the post-internet era. Marketing Theory, 9(1), 2009, pp.141-144. Available from: <http://mtq.sagepub.com/cgi/ doi/10.1177/1470593108100071 >. Accessed on: November 17, 2013.

CONLEY, L. OBD: Obsessive branding disorder: The illusion of business and the business of illusion, PublicAffairs, 2009. 
Recebido em: 20/02/2014;

Aceito em: 27/02/2014

Esta obra foi licenciada com uma Licença Creative Commons.
ELLWOOD, I. The essential brandbook- over 100 techniques to increase brand value K. Page, ed., London, 2002.

FRASER, H. M. a. The practice of breakthrough strategies by design. Journal of Business Strategy, 28(4), 2007, pp.66-74. Available from: <http://www. emeraldinsight.com/10.1108/02756660710760962>. Accessed on: April 21, 2012.

HATCH, M. J.; SCHULTZ, M. Bringing the corporation into corporate branding. European Journal of Marketing, 37(7/8), 2003, pp.1041-1064. Available from: <http://www.emeraldinsight.com/10.1108/03090560310477654>. Accessed on: November 7, 2013.

KAPFERER, J.-N. Strategic brand management: creating and sustaining brand equity 2nd ed., Kogan Page, 1997.

KORNBERGER, M. Social media in branding: Fulfilling a need. Journal of Brand Management, 18(9), 2011, pp.688-696. Available from: <http://www.palgravejournals.com/doifinder/10.1057/bm.2011.19>. Accessed on: March 6, 2012.

MCDONALD, D.D. What social media adoption model ara you following? Dennis D. McDonald's website, 2007.

MEYERS, Herbert M.; GERSTMAN, R. Branding @ the digital age, Palgrave Macmillan, 2001.

MILLWARD, Brown. The business of brands: collective intelligence for marketing today, 2009.

MOON, Michael; MILLISON, D. Firebr@nds - building brand loyalty in the internet age, McGraw-Hill, 2000.

NEUMEIER, M. The brand gap - how to bridge the distance between business strategy and design, 2003.

NEUMEIER, M. The designful company: how to build a culture of nonstop innovation, Pearson Education, 2009.

O'MALLEY, K. Marketing \& communication - what and why? Wartburg College, 2010. Available from: <http://www.wartburg.edu/marketing/branding.aspx>. Accessed on: April 4, 2011.

PARRISH, P. Design as storytelling. TechTrends, 50(4), 2006, pp.72-82. Available from: <http://link.springer.com/10.1007/s11528-006-0072-7>.

QUESENBERY, Whitney; BROOKS, K. Storytelling for user experience crafting stories for better design, Rosenfeld, 2010.

UPSHAW, L. B. Building brand identity: a strategy for success in a hostile marketplace J. Willey, ed., New York, 1995.

ZYMAN, S. The end of marketing as we know it, HarperCollins, 1999. 